Administration is charged by Congress to prevent unnecessary contamination of food, and its tolerance always takes into consideration the minimum biologically effective dosage-which may differ for different posts on different crops and which relate only to conditions in the United States.

It would be surprising if two such systems had evolved along exactly the same lines, and the factor of legal enforcement probably tends to make the Food and Drug Administration more meticulously precise in its demands. None of the sperkers suggested that its requirements were in any way fallacious, but doubts were expressed as to whether all the routine requirements were essential. A recent report from the United States, that the combination of two organo-phosphorus pesticides at residue levels within the permitted tolerance for each caused effects on experimental animals greater than could have been anticipated as normally additive, raised the question of 'potentiation'. 'This could mean that any new pesticide must be tested in combination with all others to prove its absence of hazard and, while no objection could be made were the case for such action fully proved, the greatest care was needed in ensuring that any such requirement was justified to the full, because of the implications. Theoretically, the possibility of such a happening could not logically be restricted to chemically similar compounds.

Some fear was expressed that the superficial attractiveness of stated tolerances would tend to make other countries favour the United States system, and that without the excellent facilities and high standards of operation in the Food and Drugs Administration there could arise a series of uncoordinated demands on industry, many of them quite unjustified. The analytical side is completely dependent upon the methods available, about which there is frequent disagreement even at national levels. This is one of the reasons why British officials are not enthusiastic about stated tolerances.

Toxicological work presents even more complications, not only in the choice of techniques but also in the interpretation of findings, and Dr. E. F. Edson advocated caution at this early stage, although he was satisfied that there are no grounds for active apprehension. He suggested, and was supported by Mr. J. M. Winchester, that consideration should be given to more extended feeding tests as alternatives to exhaustive chemical investigations into possible metabolites of pesticides. Both sperkers agreed with Mr. J. I. Hendrie that eloser collaboration between Government and industry is necessary in order to define more accurately the essential requirements. A Board of Trade investigation into demands of overseas countries is being carried out and should elaborate the position reviewed by the first speaker. Efforts to draw up an agreed scheme of testing are at present boing made by official and industrial toxicologists in Britain, and such a contribution could well form the basis for discussions with other countries.

Emphasis was laid on the sense of responsibility of the industry and on its desire to do all that is necessary to protect the public; but it was pointed out that if the difficulties of development of a pesticide became so onerous that the prospects of adequate commercial return appeared to be too remote, finance in the chemical industry will undoubtedly be directed into other channels-as a simple duty to shareholders. Even to-day it is widely agreed, both in the United States and Great Britain, that it is not worth while to attempt to develop a new speciality product with very limited markets, no matter how important the problem involved may be to the branch of agriculture or horticulture concerned. This applies whether the potential pesticide be highly toxic or relatively harmless to humans, since the same procedure must be followed and the same order of expenditure incurred.

In attempting to summarize the three papers, the chairman pointed out that all three contributors were making a case for co-ordination of international standards, in principle at least. It seemed possible, however, that if Britain desired some general international agreement, she may have to be the first to modify current practice. Already in Britain there are tolerances for a limited number of preservatives of foodstuffs, which include fungicides. It would not require any fundamental change to extend these to insecticides, wөedkillers, etc. If some such action could be taken there would probably be a much better chance that the system operating in Britain would be acceptable elsewhere.

Opening the discussion, Sir Solly Zuckerman paid a tribute to British industry, not only for its highly developed sense of responsibility, but also for its most co-operative attitude on the voluntary notification scheme. He refused to be perturbed by the present situation, and considered that the essential costs must be shared by government, industry and the user of pesticides. Since Britain, as well as being a leading importer of foodstuffs is also a considerable exporter of chemicals, it was doubly important that we should take a lead in this matter. He advocated caution, however, in making an approach to United Nations agencies, such as the World Health or Food and Agriculture Organizations, which could ultimately be importent and helpful, until more progress had been made in settling Britain's own admitted difficulties in chemical and toxicological testing and interpretation. If the collaboration already existing between industry and government were continued in the same spirit he was hopeful that the chief difficul. ties could be overcome.

An animated discussion followed with views and comments from chemists, toxicologists and administrators in government and in industry. It was clear that everybody concerned was well aware of the difficulties, but there was less unanimity on how to overcome these. A tendency to generalize rather too freely from particular examples was perhaps excusable with such a complex issue, particularly in view of the short period during which current regulations have been operating, either in the United States or Britain. The papers and discussions will be published in full elsewhere.

F. P. CoYne

\section{PHYSICS IN INDIAN UNIVERSITIES}

TNDER the auspices of the Indian University Grants Commission, the University of Calcutte arranged a seminar on physics which was held during September 9-11. The conference was attended by Dr. W. W. Buechner, professor of experimental physics in the Massachusetts Institute of Technology, and by delegates from almost all the universities in India at which physics is taught at a postgraduate level, together with representatives from a number of other research institutes. The second and third days of the seminar were devoted to papers on nuclear physics and cosmic rays. 
The morning and afternoon sessions of the first day were allotted to a discussion of the teaching of postgraduate physics in Indian universities. While welcoming the guests, Dr. P. C. Bhattacharya, head of the Department of Physics, University of Calcutta, gave a brief account of his Department, first established in 1916, in which such eminent scientists as Sir C. V. Raman, Dr. D. M. Bose, the late Dr. M. N. Saha, Dr. S. K. Mitra and Prof. S. N. Bose worked and inspired the younger generation. Dr. D. M. Bose, director of the Bose Institute, in his presidential address, first gave a description of the teaching of physics in his college days in the Presidency College, Calcutta (1905-6), in Cambridge (1907-11), in London (1911-12) and Berlin (1914-18), under J. C. Bose, J. J. Thomson, C. T. R. Wilson, Jeans, Watson, Rubens, Max Planck and others. He also mentioned the methods of teaching of Einstein and Nernst. As a professor of physics, Dr. Bose revised the M.Se. syllabus in physics for the University of Calcutta in 1920 on the lines adopted by Planck. Dr. Bose discussed the feasibility of devising a satisfactory syllabus for teaching postgraduate physics in all the universities in India. Young men after getting the degree of M.Sc. generally take up (1) the teaching of physics in high schools and colleges, (2) research work in the universities, government laboratories and industry, (3) administrative work in government, technical and commercial services; and Dr. Bose stressed the importance of the first category to the economic and technological development of India.

Finally, Dr. Bose dealt with the importance of encouraging nuclear research through non-governmental agencies. Like Brookhaven National Laboratory for research and training in nuclear physics which is managed by nine United States universities, he pleaded that similar laboratories should be established in India on a regional basis.

Dr. Buechner gave an impression of his two months tour of India, visiting various universities and institutions. He remarked upon certain similarities between India and the United States as regards the type of student who undertakes postgraduate studies and the lack of financial support for universities. One striking difference is that in the United States, although there are a number of laboratories managed by the government or by industry, the prime centre of research is the university. This is not the case in India, where Dr. Buechner had the impression that the universities are steadily declining in importance, being overshadowed by government and other research institutions. Without government support research cannot flourish, and without research any programme of postgraduate teaching will fail. It is the responsibility of the Indian universities to put forward their claims to the authorities and to make them understand the place of research in the university and in postgraduate teaching.

Sixteen other speakers, mostly heads of departments of physics in various universities, also gave accounts of the methods of postgraduate teaching prevailing in their respective universities, with suggestions for improvements.

The teachers of physics present at the seminar, representing almost all the universities of India, finally resolved (inter alia) that :

"As the main burden of the training of future physicists must be borne by the universities, the University Grants Commission is requested to ensure that the emoluments, research grants and other facilities available to the university teachers are adequate and in no way inferior to those available to people in similar positions in the National Laboratories or elsewhere."

The conference viewed with concern the generel tendency for men with the best university qualifications to leave their universities for more lucrative jobs elsewhere, including the administrative services in which a knowledge of physics is not necessary, when their knowledge is urgently required for teaching work in the universities. "The best tools must be retained for manufacturing the tools themselves, for this in turn will produce better and better tools." P. C. Bhattacharya

\section{WATER QUALITY PROBLEMS IN THE UNITED KINGDOM}

A $T$ a meeting of the Society for Visiting Scientists held on Oetober 22, under the chairmanship of Mr. H. W. Cremer, there was an interesting discussion on "Water Quality Problems in the United Kingdom" following short papers on different aspects of this subject by Dr. G. Carter (Metropolitan Water Board), Dr. A. Key (Ministry of Housing and Local Government), and Dr. B. A. Southgate (Water Pollution Research Laboratory).

There is a growing demand for water of good quality, not only for domestic use, but also for industry-in some processes of manufacture the specifications to which the water must conform are more stringent than for drinking water-and for agriculture, particu. larly for drinking water for attested cattle. To produce water of this high quality from surface supplies a wide range of treatment processes is used; the Metropolitan Water Board, for example, treats Thames water by storage, filtration through rapid and slow sand-filters, and chlorination; industrial supplies may be treated in plants resembling those of municipal water undertakings, and for some purposes may be de-ionized by exchange processes; drinking water for cattle is often chlorinated before use.

At the same time the total volume of water asked for is also rapidly increasing. Usually, whether used for domestic or industrial purposes, the volume returned to a stream is substantially the same as that extracted, the problem being so to treat it that it can, if necessary, be used again farther downstream. For sewage, satisfactory methods of treatment are available, and by taking special precautions-as, for example, by passing the treated sewage effluent through sand-filters-the liquid finally returned to a river may be brought to a high standard of quality, and indeed would often be suitable, after chlorination, for some industrial purposes. Waste waters from industrial processes, having a much wider range of composition, present more difficult problems in treatment.

The large amount of research on these problems now being undertaken, or sponsored, by industry was widely recognized in the discussion. Several speakers referred to the difficult situation which may arise if there is any great increase in the practice of irrigating farm crops in the drier parts of Britain; water used in this way is lost from the cycle of use and re-use, being, of course, evaporated or transpired by plants. 